\title{
A Review: Thin Protective Coating for Wear Protection in High-Temperature Application
}

\author{
Mokhtar Awang *, Amirul Amin Khalili and Srinivasa Rao Pedapati \\ Department of Mechanical Engineering, Universiti Teknologi PETRONAS, Seri Iskandar 32610, Malaysia; \\ amirul_17008225@utp.edu.my (A.A.K.); srinivasa.pedapati@utp.edu.my (S.R.P.) \\ * Correspondence: mokhtar_awang@utp.edu.my; Tel.: +605-368-7204
}

Received: 21 October 2019; Accepted: 12 December 2019; Published: 25 December 2019

\begin{abstract}
Earning trust among high strength material industrialists for its sophistication, thin protective coating has gained its own maturity to date. As a result of active development in the industries, working tool has the capability of fabricating high strength materials with remarkable durability. For example, unwanted tool wear due to thermally softening problems can be avoided. Therefore, the solution for that is protecting the tool with a thin protective coating that can be coated by various coating deposition methods. With the thin protective coating itself possessing remarkable degree of chemical and mechanical properties, the combination of both makes the thin protective coating lead to a useful extend. This paper provides a review of various research activities and various developments in the wear prone industries. Researchers have explored a number of thin protective coatings for the last century to provide a valuable guide for a most practical option. With the state of the art development of the coating methods such as electrodepositing, radio frequency ion source implantation, electron beam implantation, plasma-sprayed coating deposition, flame-sprayed coating deposition, chemical catalytic reduction deposition, vacuum-diffused deposition, vapor deposition, chemical vapor deposition, physical vapor deposition, plasma arc deposition, and some others, this paper presents the continuous development on the enhancement of the capability of the working tool chronologically since the last century. Such development was studied in connection with the ability to outlast the performance of working tool, which elevates expectations that thin protective coatings are no longer extended far beyond.
\end{abstract}

Keywords: wear; wear protection; thin protective coating; coating method

\section{Introduction}

During the last few decades, materials have evolved towards being environmentally friendly, having superior strength and properties, possessing less weight, and having lower production cost [1-3]. Rabinowicz's principle of abrasive wear says that a material will scratch another material if it is harder than the later [4]. The research suggests that in order to prevent abrasive wear, one could have a harder material for a working tool than the material that is subjected to the work itself [5]. Earning trust among high strength material industrialists for its sophistication, thin protective coating has gained its own maturity due to its remarkable durability; unwanted tool wear due to thermally softening problems can be avoided [6-12]. There is a need for industrial materials to be machined, therefore, developing tools that suit these materials better has also gained its popularity. Reinforcement of the tool comes into several branches; the reinforcement of the tool's substrate, better design, as well as having a thin protective layer on the substrate. Thin protective layer comes in variety of families: transition metal family, post-transition metal family, reactive non-metal family, lanthanides family, and hybrid coatings. Good coating criteria should include: 
1. High temperature resistant

2. Good strength

3. Great thermal fatigue

4. Chemically inert

5. Low friction coefficient

6. Low cost

With the state of the art development of the coating methods such as electrodepositing, radio frequency ion source implantation, electron beam implantation, plasma-sprayed coating deposition, flame-sprayed coating deposition, chemical catalytic reduction deposition, vacuum-diffused deposition, vapor deposition, chemical vapor deposition, physical vapor deposition, plasma arc deposition, and some others, thin protective coating has evolved.

Among the popular developments and researches that had been done on thin protective coating are polymer, ceramic, TiN, TiAlN, AlCrN, diamond like carbon (DLC), diamond, WS2 (WS2 = Tungsten disulfide), and stellite. This paper presents the continuous development on the enhancement of the capability of the working tool chronologically and provides a review of various research activities and various developments in the tool working industries. Researchers have explored a number of thin protective coatings for the last century to provide a valuable guide for a most practical option. Such development was studied in connection with the ability to outlast the performance of working tool which elevates aspirations that thin protective coatings are no longer far beyond extent.

\section{State of the Art}

Intrinsically, the growth of a coating is a complex phenomenon that the successfulness of growing such phenomena had been studied over the years. In earlier development, researchers have utilized the deposition method such as chemical bath, laser, and detonation. Along with the improvement of the technology, deposition methods involved chemical vapor deposition, physical vapor deposition, and many more. A summary of coatings and their methods were listed in Tables 1-4.

Camp [13] had done a chipping and abrasion test in 1928 for a coating on metal to determine the coating quality on a strong aluminum. The thickness of the costing was 0.0001 inch and it was done by an abrasion testing machine made by stainless steel alloy. The author's findings from the work are the pointing raking tool is the most suitable for the testing and that the differences in abrasion quality range from $2000-46,000$.

Hothersall [14] in 1930 came out with several factors that influenced the properties and surface smoothness of an electrodeposited copper. Commercially available copper deposits were widely used at that present time. Reduction in the cost of the deposition was the main intention. Several tests had been done by the author, out of which some factors came out, inducing the more acceptable deposition of the copper coating. The hardness of the copper coating recorded 63 and 38 hardness values. The author also found that the presence of impurities in the solution influences the growth of the copper, and the addition of the agents will affect the hardness of the cooper.

Monk and Ellingham [15] in 1935 had done a study on alkaline stannate electrodepositing copper-tin alloy, also known as bronze and nickel. Copper-tin requires a solution that has a complex oxalate. Acidified stannous sulphate had gained popularity due to its successfulness in depositing and breaking down the growth of the crystal. The authors had found out that the experiment successfully deposited thin deposits with a bright brilliant metallic glance containing up to $25 \% \mathrm{Ni}$. The hardness of the coating was seven times harder than the deposited tin.

Du Rose [16] in 1946 wrote about the protective value of lead and lead-tin that were adopted on steel. The use of lead had increased due to the war-time metal usage restriction. This sudden vast usage brought up the lack of information on the coating of the lead. Several test methods were done by the author, and the results were compared, and the effect of metal undercoat of throwing paper and thickness effects associated with the agent in the plating bath were studied. The author found that 
an increase in the concentration of glue gives better covering and throwing power and exhibits good corrosion resistance to the steel, the deposited substrate remains light, and there was an increase in uniformity of the coating over time.

Table 1. Published works on transition metal coating material with its substrate.

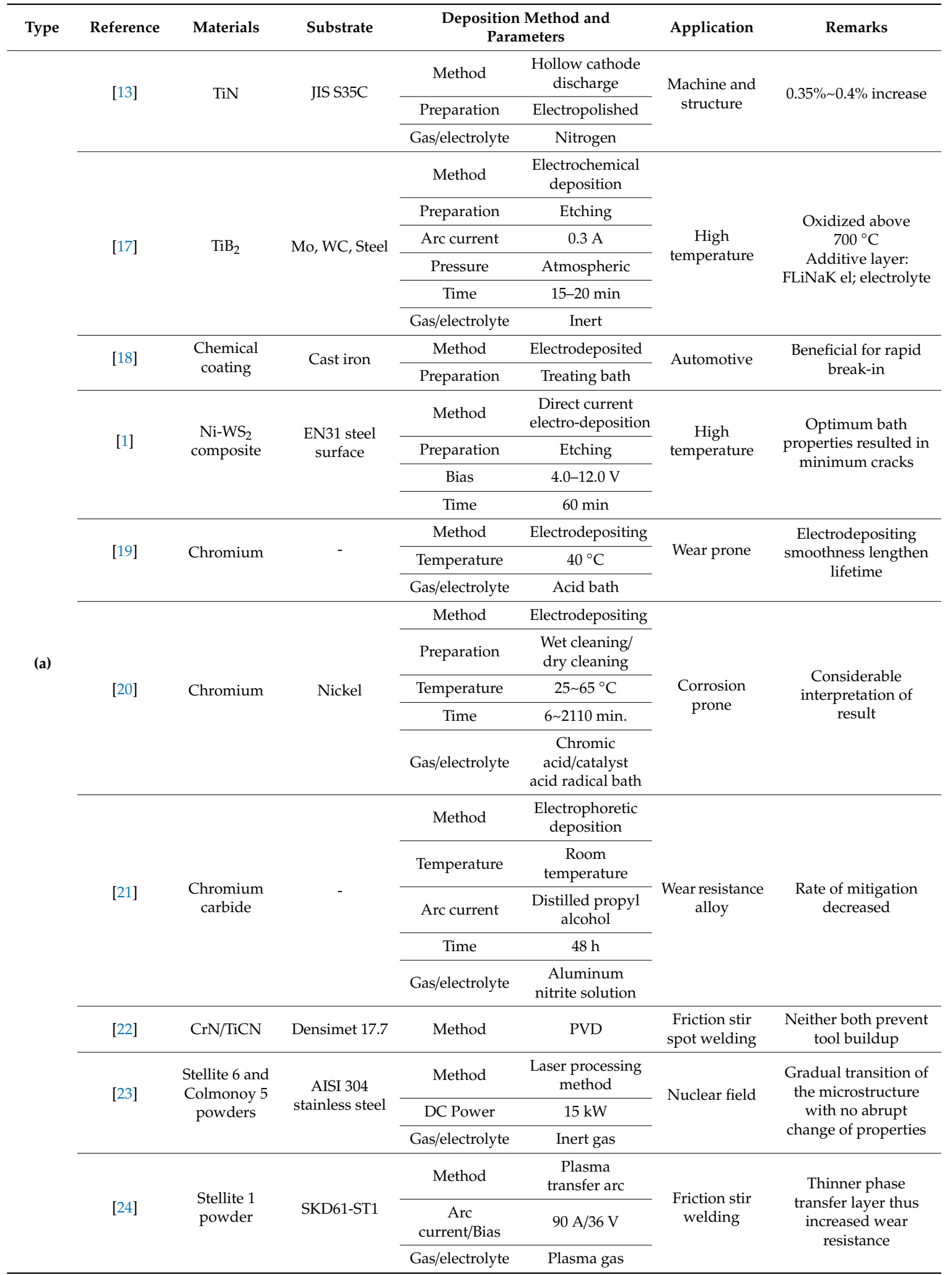


Table 2. Previous works on post-transition metal and reactive non-metal coating material with its substrate.

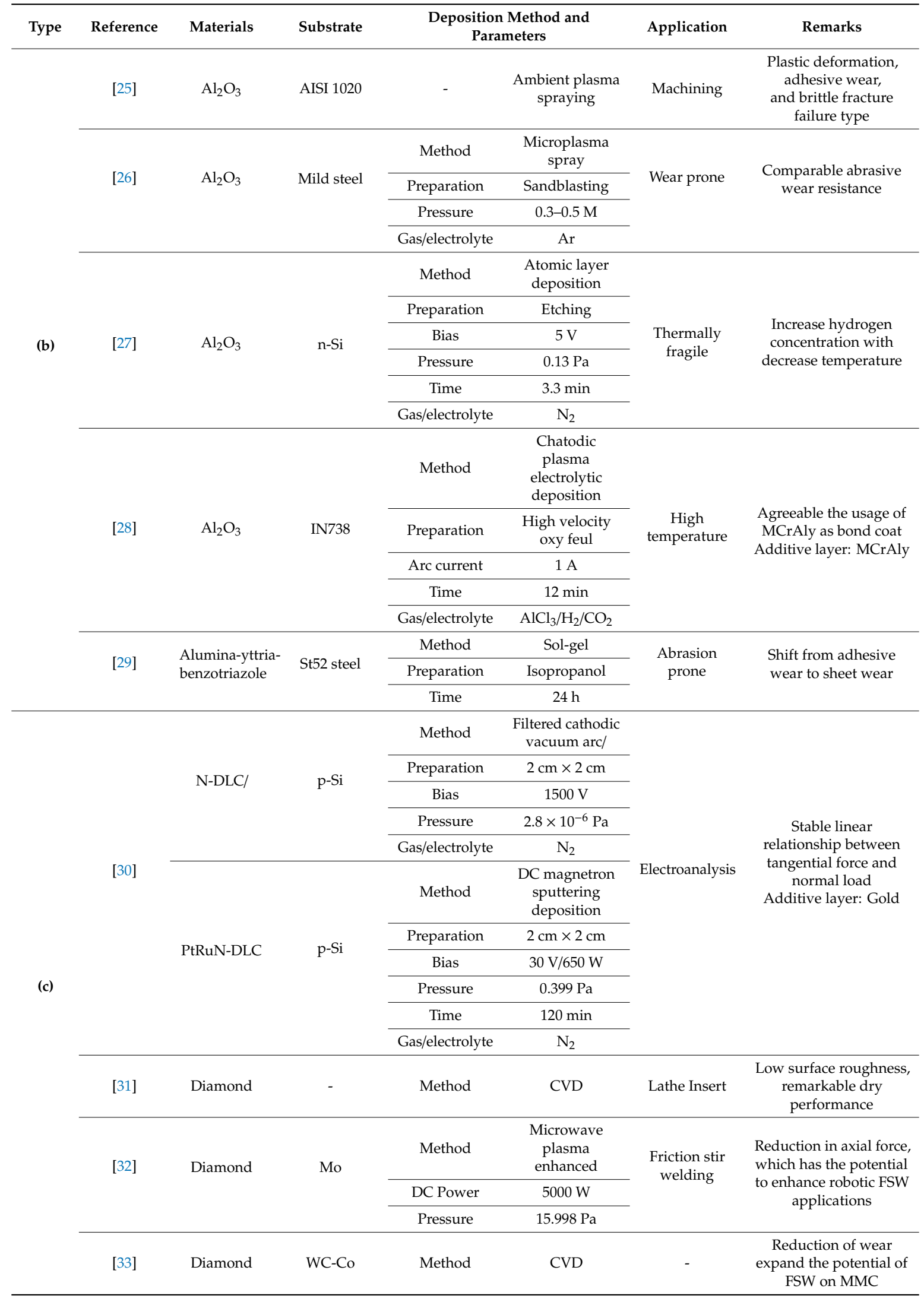


Table 3. Previous works on lanthanides coating material with its substrate.

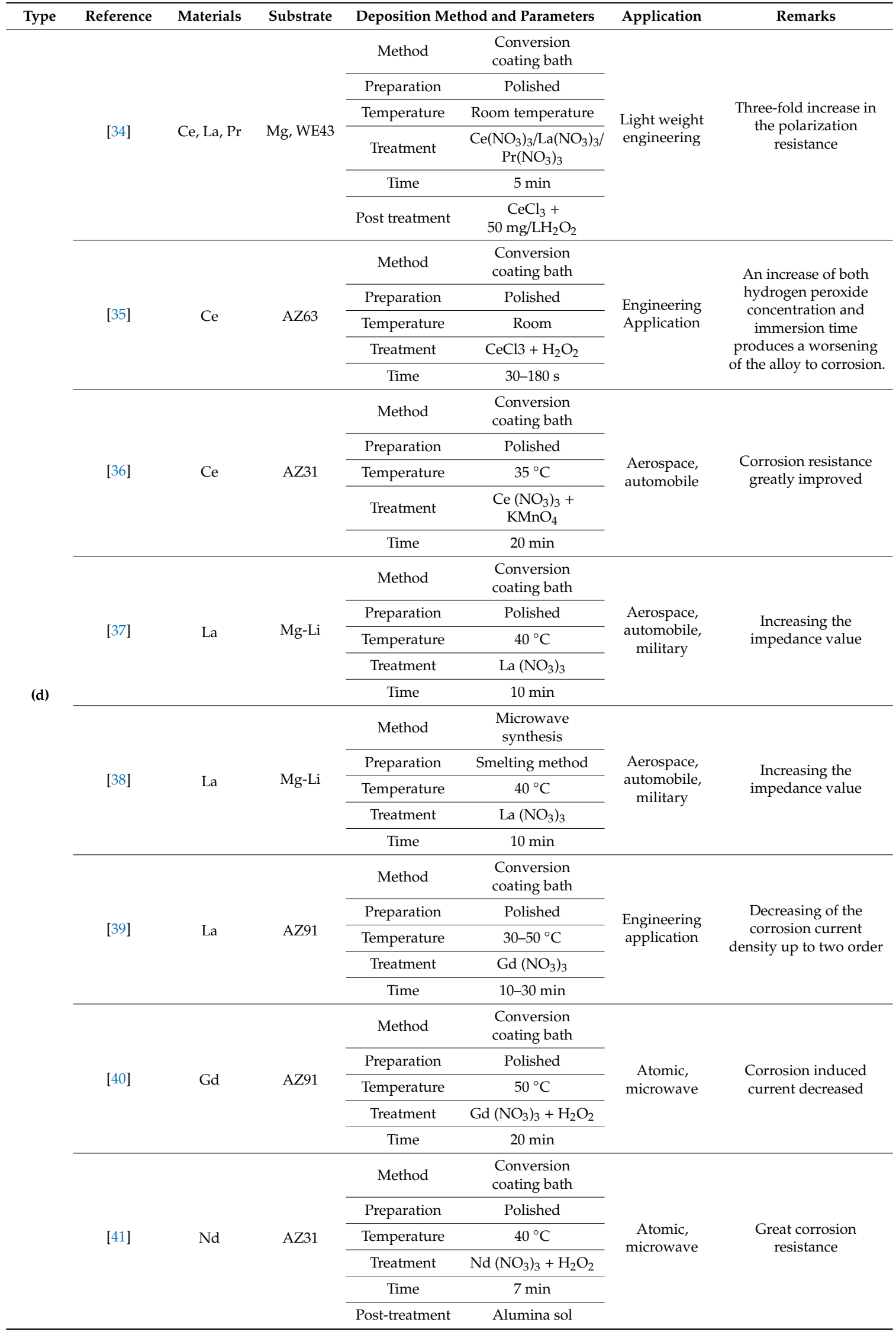


Table 3. Cont.

\begin{tabular}{|c|c|c|c|c|c|c|c|}
\hline Type & Reference & Materials & Substrate & \multicolumn{2}{|c|}{ Deposition Method and Parameters } & Application & Remarks \\
\hline & \multirow{5}{*}{ [42] } & \multirow{5}{*}{$\mathrm{Nd}$} & \multirow{5}{*}{ AZ91 } & Method & $\begin{array}{l}\text { Conversion } \\
\text { coating bath }\end{array}$ & \multirow{5}{*}{$\begin{array}{l}\text { High toxicity } \\
\text { compound } \\
\text { replacement }\end{array}$} & \multirow{5}{*}{$\begin{array}{l}\text { Improved corrosion } \\
\text { resistance }\end{array}$} \\
\hline & & & & Preparation & Polished & & \\
\hline & & & & Temperature & $50{ }^{\circ} \mathrm{C}$ & & \\
\hline & & & & Treatment & $\mathrm{Nd}\left(\mathrm{NO}_{3}\right)_{3}+\mathrm{H}_{2} \mathrm{O}_{2}$ & & \\
\hline & & & & Time & $20 \mathrm{~min}$ & & \\
\hline & \multirow{5}{*}{ [43] } & \multirow{5}{*}{$\operatorname{Pr}$} & \multirow{5}{*}{ AZNd } & Method & $\begin{array}{l}\text { Conversion } \\
\text { coating bath }\end{array}$ & \multirow{5}{*}{$\begin{array}{l}\text { Biomedical } \\
\text { application }\end{array}$} & \multirow{5}{*}{$\begin{array}{l}\text { Less concentration will } \\
\text { be deposited in a } \\
\text { short time }\end{array}$} \\
\hline & & & & Preparation & Ultrasonic cleaned & & \\
\hline & & & & Treatment & $\operatorname{Pr}\left(\mathrm{NO}_{3}\right)_{3}$ & & \\
\hline & & & & Time & $30 \mathrm{~s}$ & & \\
\hline & & & & Method & $\begin{array}{l}\text { Conversion coating } \\
\text { bath }\end{array}$ & & \\
\hline & \multirow{5}{*}{ [44] } & \multirow{5}{*}{ Sm } & \multirow{5}{*}{ AZ91 } & Method & $\begin{array}{l}\text { Conversion } \\
\text { coating bath }\end{array}$ & \multirow{5}{*}{$\begin{array}{l}\text { High toxicity } \\
\text { compound } \\
\text { replacement }\end{array}$} & \multirow{5}{*}{$\begin{array}{l}\text { Improved corrosion } \\
\text { resistance of the } \\
\text { relevant coated } \\
\text { substrate }\end{array}$} \\
\hline & & & & Preparation & Polished & & \\
\hline & & & & Treatment & $\mathrm{Sm}\left(\mathrm{NO}_{3}\right)_{3}$ & & \\
\hline & & & & Time & $20-50 \mathrm{~min}$ & & \\
\hline & & & & Method & $\begin{array}{l}\text { Conversion } \\
\text { coating bath }\end{array}$ & & \\
\hline & \multirow{5}{*}{ [45] } & \multirow{5}{*}{ Y } & \multirow{5}{*}{ AZ91D } & Method & $\begin{array}{l}\text { Conversion } \\
\text { coating bath }\end{array}$ & \multirow{5}{*}{$\begin{array}{l}\text { Aerospace, } \\
\text { automobile }\end{array}$} & \multirow{5}{*}{$\begin{array}{l}\text { Corrosion current } \\
\text { density had been } \\
\text { decreased two orders } \\
\text { of magnitude }\end{array}$} \\
\hline & & & & Preparation & Polished & & \\
\hline & & & & Temperature & $30^{\circ} \mathrm{C}$ & & \\
\hline & & & & Treatment & $\begin{array}{c}\mathrm{Y}\left(\mathrm{NO}_{3}\right)_{3} \\
(\mathrm{Y}-\mathrm{Y} \text { ttrium) }\end{array}$ & & \\
\hline & & & & Post-treatment & $\begin{array}{l}\text { Silica sol + } \\
\text { air dried }\end{array}$ & & \\
\hline
\end{tabular}

Ruth et al. [46] in 1960 wrote on the vapor-deposited single-crystal germanium (Ge). Ge layer was formed on substrates by the thermal decomposition of Ge. The single-crystal nature of the layers has been established by $\mathrm{x}$-ray, and electron diffraction examination, and electrical measurements. The crystal growth rate varies with crystal direction, and under certain conditions, Ge whiskers appear. It has been suggested that the heat treatment phenomenon is the result of the rapid diffusion and subsequent deactivation (at dislocations and other sites) of the interstitials at elevated temperatures. The removal of these excess donor centers gradually converts the material to $p$ type, in which the uncompensated acceptor levels of the lattice vacancies dominate the conduction. The over-all model suggested is, thus, one in which a high degree of crystal perfection exists on a macroscopic scale, as indicated by the various tests for single crystal structure. Mobility behavior at low temperatures indicates the large concentration of imperfections present on atomic scale.

Shesternenkov [47] in 1968 reported that since plasma-sprayed and flame-sprayed methods had been extensively covered and the coating was prone to porosity, detonation coating resulted. Detonation coating, in basic terms, is the detonation velocity of the rate of motion of the phase boundary between the reaction products and the unreacted mixture of substrate. This boundary is formed by the flame front and the detonation wave which precedes it. In contrast to the normal damped shock waves, the detonation wave is powerful, stationary, undamped shock wave. The detonation method of coating is not to be recommended in cases where considerable wear of the surface is permitted. The coating of the working edged of metal cutting tools is not recommended either, because thin layers do not permit repeated sharpening of the tool. The detonation rapidity process in the gun barrel undoubtedly increases the possibility substances used in coatings are vaporized or decomposed at high temperature. The high temperature and pressure, which increase during the explosion of the gas 
mixture, may make gas detonation an effective way for the synthesis of chemical compounds with mow composition and structure.

Table 4. Previous works on hybrid coating material with its substrate.

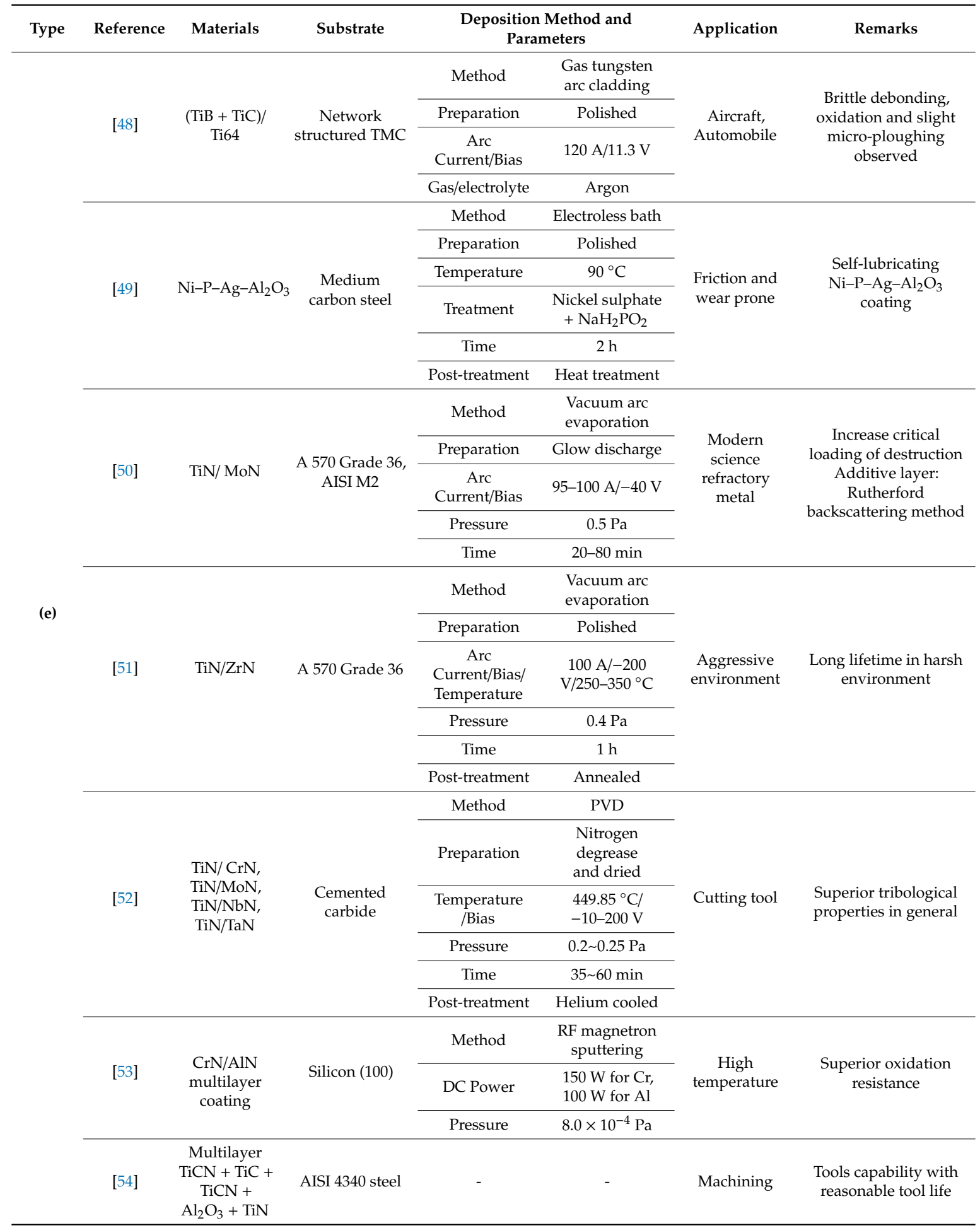

Mikhailov et al. [55] in 1969 had done a work on endurance and wear resistance of steels with vacuum-diffused coatings. The fatigue strength and wear resistance of steels St3, P-1, EI-802, and EI-612 after vacuum-diffusion chromizing, siliciding, and boriding were studied. It was shown that the wear resistance of carbon steels is increased more than 20-fold by boriding, being approximately doubled 
by chromizing, and increased 1.3 times by siliciding. Of the steel alloys, only steel EI-612 has its wear resistance increased by vacuum chromizing. The fatigue strength was reduced in every case by $20 \%$ to $50 \%$.

Guzman et al. [56] in 2016 had carried out an experiment in pursue of studying the effectiveness of single layer hafnium nitrite as a thin protective coating applied onto cutting tools. The deposition was by a radio frequency magnetron sputtering physical vapor deposition, and it was $52 \%$ ionic-covalent hafnium nitrite thin protective coating This brings the great thermal, great hardness, and high melting point properties, and electrical conductivity of the thin protective coating. Several tests had been carried out in this experiment to an extent for the author to conclude that this single layer hafnium nitrite as a thin protective coating when applied onto cutting tool, would improve the surface finishing of the working material, lowering the microcracking. With that said, this thin protective layer will benefit the machining industries by decreasing production time, increasing the quality of the work, and reducing the impact of wear.

\subsection{Transition Metal}

Shiozawa and Han [57] had done a study on the effect of TiN thin protective coating on low-cycle fatigue behavior of steel coated by physical vapor deposition method. The production of thin layers of titanium nitride on the surfaces of various engineering components by a variety of techniques has received considerable attention in the past few years. A number of superior properties of TiN thin film produced by physical vapor deposition or chemical vapor deposition methods, such as high hardness, good wear, chemical stability, corrosion resistance, relatively good adhesion of the films, and an attractive color, may be attributed to surface improvement of metals. In this experiment, the author found that fatigue strength increases after being coated by the titanium nitrite.

Rybakova [17] in 2011 utilized TiB2 as a thin protective coating produced by high-temperature molten salt electrolysis detailing more on the study of the electrochemical process $\left(\mathrm{TiF}_{6}{ }^{2-}\right.$ and $\mathrm{BF}_{4}^{-}, 600 \sim 700{ }^{\circ} \mathrm{C}$ ) to learn better on the reaction behavior of an electrolytes. The process of electrochemical deposition takes place by using two solutions, which are the molten eutectic mixture and a chloride-fluoride mixture. Ranging from 1646 to $3400 \mathrm{HV}_{0.05}$, TiB2 thin protective coating exhibited residual stress in ranges of $-0.7 \mathrm{GPa} \sim-2.2 \mathrm{GPa}$, and roughness Ra values of $400 \sim 1300 \mathrm{~nm}$. The study shows the surface of the electrochemically coated TiB2 thin protective coating taken by atomic force microscope and uneven surface morphology appears due to the usage of the pulsed plating techniques. The author concludes that the electrolyte used in this study presents a good quality of melt, a great window potential of electrochemical properties, lower melting point, and lower process parameter when compared to other fluoride salts. The optimum deposition temperature found by the author for deposition of TiB2 thin protective coating was $650^{\circ} \mathrm{C}$. Sandblasting was found to be effective to achieve high quality coating. Electrochemically coated TiB2 thin protective coating also was found effective in protecting the substrate from corrosion under a test carried out, with no geometrical change and no trace of corrosion visibly.

Young and Davis [18] in 1947 had done a work on the chemical coating's wear and scuff resistance. The chemical coatings studied in this work were iron oxide, manganese-iron phosphate, and caustic-sulfur. The phosphate coated cat iron had proven to benefit the cast iron. Manganese-iron phosphate, on the other hand, gave satisfactory results with the operation tested. The matte finish caustic-sulfur acted like a barrier to prevent diffusion. Iron oxide provided excellent result on the test done, with minimal failure reported.

Saini et al. [58] in 2016 came with Ni-WS 2 composite as a thin protective coating. $\mathrm{WS}_{2}$ are well known for their hexagonal structure and their remarkable properties. Providing a low friction coefficient, the $\mathrm{WS}_{2}$ exhibit smoothness, and firm adhesion to the substrate. The combination of $\mathrm{Ni}$ with the $\mathrm{WS}_{2}$ makes the compound less brittle with enhanced properties such as adhesion strength, density of the thin protective coating, and the wear resistance of the thin protective coating. Prior to the thin protective coating deposition, the substrate is cleaned, and its surface atoms are energized by weak 
$\mathrm{HCl}$ solution and an activating solution. The thin protective coating is then coated by using a direct current electro-deposition method. The scanning electron microscope image of the $\mathrm{Ni}-\mathrm{WS}_{2}$ composite as a thin protective coating ensures that the uniform coating is achieved without any imperfection on the substrate. The thin protective coating was concluded to exhibit improved wear resistance of the substrate.

Killeffer [19] mentioned in his work in 1927 that, since 1854, Bunsen had successfully deposited chromium to a substrate by using electrodepositing method but to an extent that it was still in early phase. The deposited metal still could not be used and was not industrially available. In his work, he had introduced the chromium coating in pursuing an aid to vast industries that demand materials that are wear, abrasion, and corrosion resistant. The author had found that chromium had successfully been deposited onto a substrate using electrodepositing method and it was ready for commercial availability, since the thin protective coating exhibit wear, abrasive, and corrosion resistant with flying colors.

Dubpernell [20] in 1941 had conducted a work that presented the preparation of chromium. Chromium was famous in final finish for its high hardness, low friction coefficient, and good corrosion resistance. The chromium plating process utilized chromic acid and acid radical bath catalyst. The author had concluded that the chromium plating would speed up at temperature of $65^{\circ} \mathrm{C}$ and after several tests and experimental works with several parameters used, the chromium was successfully adopted and believed to continue to be used in the future.

Furman and Apininskava [21] in 1974 had done a study on chromium carbide coated by electrophoretic deposition method. Chromium carbide had been used in the manufacturing industry for its wear resistance properties.

Heideman [22] in 2014 had done a study on Friction stir spot welding of a 6061 Al-T6/Cu sheet utilizing $\mathrm{CrN}$ and TiCN thin protective coating. The study was aimed to prevent material buildup on the tool's tip. The issue with this study was the built-up material on the tool substrate. The author firstly cleans the tool before each weld, and later to reveal that deploying thin protective coating, would prevent the material buildup. The thin protective coating was coated using physical vapor deposition, which improved the consistency of the weld. The cause of the material buildup begins with the first contact between the welding tool and the welding material. The material was expelled into the stirring zone and remained on the tool. However, neither $\mathrm{CrN}$ nor TiCN thin protective coating seems to last well on the tool. The author concluded that the $\mathrm{CrN}$ and $\mathrm{TiCN}$ thin protective coatings were poor solutions to combat material buildup on the tool tip.

Cochia et al. [23] in 1987 examined the microstructural aspects of wear-resistance satellite and colmonoy coatings by laser processing methods. Two coatings were produced, using a high-power $\mathrm{CO}_{2}$ laser of $15 \mathrm{~kW}$ maximum power as a heat source to melt and bind Stellite and Colmonoy powder onto a substrate of AISI 304 stainless steel. The processing parameters were optimized in order to obtain a uniform surface layer. The authors concluded that the bonding region shows a favorable dispersion of elements in a relatively narrow zone, which resulted in a gradual transition of the microstructure with no abrupt change of properties.

Chen et al. [24] in 2019 performed an experiment on the wear study of stellite 1 thin protective coating against friction stir welding of 5083 aluminum alloy. Several tools were compared such as tempered SKH-51, annealed SKH-51, tungsten carbide-cobalt (TCC), and plasma transfer arc coated stellite 1 SKD61. Adopted using plasma transfer arc, stellite 1 thin protective coating exhibited approximately 650 hardness value. The cross section of the stellite 1 thin protective coating was visualized in this paper. The 5083 aluminum alloy exhibited the chemical composition of $\mathrm{Si}, \mathrm{Fe}, \mathrm{Cu}$, $\mathrm{Mn}, \mathrm{Mg}$, Sn, Ti, Cr, and $\mathrm{Al}$ of 0.40, 0.40, 0.10, 0.45, 4.50, 0.25, 0.15, 0.05, and Bal., respectively. The wear rate, solidification structure, and wear mechanism were studied. It is concluded that the structure of the dilution effect between the substrate and the stellite 1 thin protective coating was not obvious. The authors also found that the thin protective coasting exhibited better wear than tempered SKH-51 and annealed SKH-51, and slightly lower than conventional TCC tool. 


\subsection{Post-Transition Metal}

Fernandez et al. [25] in 1995, conducted an experiment to study the behavior of $\mathrm{Al}_{2} \mathrm{O}_{3}$ thin protective coating. The coating was coated by an ambient plasma spraying method. The thin protective coating exhibits a good coating characteristic. This $0.3 \mathrm{~mm}$ thin protective coating has properties such as grain size, hardness value, elastic modulus, porosity, roughness Ra, adherence, and density which are 53-68 $\mu \mathrm{m}, 800 \mathrm{Hv} 0.3,350 \mathrm{GPa}, 5 \%$ to $7 \%, 2 \mu \mathrm{m}, 59-63 \mathrm{MPa}$, and $3.3 \mathrm{~g} \mathrm{~cm}^{-3}$, respectively. Multiple tests were conducted such as wear test under dry sliding to evaluate the comparison of the wear in linear and conformal contacts, the wear under multiple loads, and the influences of velocity against wear. The second test was a wear test under lubricated sliding to study the comparison of wear of linear and conformal contact with lubrication, the influence of loads with lubrication, and the influences of the speed under lubrication. The last test was the scanning electron microscope (SEM) analysis on the worn surfaces: the worn on the dry sliding and worn on the lubricated sliding. Authors found that the wear behavior of $\mathrm{Al}_{2} \mathrm{O}_{3}$ thin protective coating is different both in conformal and linear contacts. Its wear rate had lower conformal contacts when compared to linear contacts. Moreover, there is a higher wear observed in dry sliding which remained low in the lubricated sliding. The failure mode of $\mathrm{Al}_{2} \mathrm{O}_{3}$ thin protective coating was observed as plastic deformation, adhesive type of wear, as well as the brittle fracture.

$\mathrm{Li}$ and Sun [26] in 2004 discussed about the $\mathrm{Al}_{2} \mathrm{O}_{3}$ thin protective coating microplasma-sprayed, by using a novel hollow cathode torch. The high density of energy and the high temperature of the plasma jet are useful to overcome the problem arising from the refractory materials that were difficult to coat by conventional thermal spray. Multiple tests had been carried out to establish the efficiency of this method such as optical microscopy, scanning electron microscopy, and x-ray diffraction analysis for the characterization of the surface. Well-flattened surface characterization of the $\mathrm{Al}_{2} \mathrm{O}_{3}$ thin protective coating was deployed. As a result, this low watt microplasma-sprayed hollow cathode torch produces a comparable result with the 40-kW conventional plasma jet. Higher plasma power also contributes to the loss of the $\mathrm{Al}_{2} \mathrm{O}_{3}$ when subjected to the abrasive wear. The higher the plasma power, the greater the abrasive wear resistance, thus reducing the weight losses.

Groner et al. [27] produced a work back in 2004 investigating atomic layer deposition coated $\mathrm{Al}_{2} \mathrm{O}_{3}$ thin protective coating in a low $33 \sim 177^{\circ} \mathrm{C}$ temperature environment with the exposure of $\mathrm{H}_{2} \mathrm{O}$ and the $\mathrm{Al}\left(\mathrm{CH}_{3}\right)_{3}$. Useful for those applications that were sensitive to temperature, this atomic layer deposition coating method demonstrated a great property that was comparable to the same coating method with working temperature higher than 177. This technique promotes good surface roughness, lower leakage currents, high dielectric constant, and excess $1 \AA /$ cycle growth rate. Moreover, despite the decrease of the densities and the rising of the concentration of the hydrogen, this lower temperature method still exhibits good properties. Table 5 shows the parameters used in the coating process of $\mathrm{Al}_{2} \mathrm{O}_{3}$ thin protective coating using $33 \sim 177^{\circ} \mathrm{C}$ temperature range with atomic layer deposition. According to the authors, improvisation of the design of the reactor and the usage of oxygen solves the increase in the cycle time due to the lower reaction rates and longer purging time for the reactant. Moreover, the atomic layer deposition coated $\mathrm{Al}_{2} \mathrm{O}_{3}$ thin protective coating exhibits lower $\mathrm{CO}_{2}$ diffusion when working.

Table 5. $\mathrm{Al}_{2} \mathrm{O}_{3}$ coating properties [27].

\begin{tabular}{ccccccc}
\hline \multirow{2}{*}{ Parameter } & \multicolumn{6}{c}{ Growth Temperature/ ${ }^{\circ} \mathbf{C}$} \\
\cline { 2 - 7 } & $\mathbf{1 7 7}$ & $\mathbf{1 2 5}$ & $\mathbf{1 0 2}$ & $\mathbf{8 0}$ & $\mathbf{5 8}$ & $\mathbf{3 3}$ \\
\hline TMA exposure time/s & 1 & 1 & 1 & 1 & 1 & 1 \\
Purge time/s & 5 & 5 & 5 & 5 & 10 & 20 \\
Water exposure time/s & 1 & 2 & 2 & 2 & 2 & 2 \\
Purge time/s & 5 & 10 & 20 & 20 & 30 & 180 \\
Mass gain/cycle $\left(\mathrm{bg} / \mathrm{cm}^{2}\right)$ & 38 & 39 & 36 & 34 & 30 & 28 \\
\hline
\end{tabular}


Bahadori et al. [28] conducted a study in 2013 with $\mathrm{Al}_{2} \mathrm{O}_{3}$ ceramic thin protective coating as a ceramic thermal barrier coating on an IN738 Inconel coated by MCrAly. The $\mathrm{Al}_{2} \mathrm{O}_{3}$ ceramic thin protective coating was deposited by using cathodic plasma electrolytic deposition to study the formation of $\mathrm{Al}_{2} \mathrm{O}_{3}$ ceramic thin protective coating on IN738 Inconel coated by MCrAly. Several tests were conducted such as scanning electron microscope for the ceramic coating morphology, X-ray diffraction spectra for the composition of the coating, micro hardness test for the average hardness of the coating, and elemental test for the distribution of the ceramic coating's element. The authors concluded that the coated substrate is mainly $\mathrm{Al}_{2} \mathrm{O}_{3}$ and $\mathrm{Ni}_{3} \mathrm{Al}$. The different level of $\mathrm{pH}$ has some effects on the microstructure of the thin protective coating. The higher the $\mathrm{pH}$, the more continuous the spheroids on the surface. Figure 1 illustrated the coating morphology of the coating.

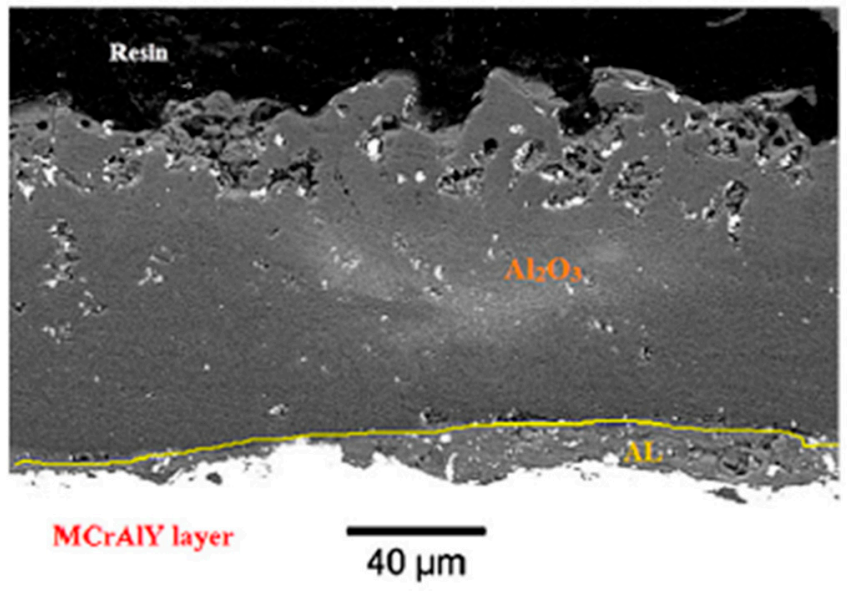

Figure 1. Ceramic coating morphology of the $\mathrm{Al}_{2} \mathrm{O}_{3}$ ceramic thin protective coating on the MCrAlY coated IN738 Inconel [28].

Dezfuli and Sabzi [29] had done a study in 2018 on the influences of yttria and benzotriazole inhibitor agents doping on the abrasion and corrosion behavior of alumina-based thin protective coating. Self-healing thin protective coating was greatly studied due to the capacity of their application in industries. The film will heal itself overtime with the help of the inhibitor agent doped into the thin protective coating. The healing mechanism of the triple-component alumina-yttria-benzotriazole coating was explained in this paper. The addition of yttria and benzotriazole into the ceramic-based coating is believed to prevent defect formation. The St52 steel substrate was prepared by degreasing and then acetone washing. The substrate was then immersed in alumina isopropanol-based solution that had been mixed with ethyl acetoacetate, aluminum-tri-sec-butylate, deionized water, and citric acid. The alumina-yttrium-benzotriazole solution is prepared by adding yttrium nitrite hexahydrate to alumina-yttria solution and benzotriazole solution. After several tests, the authors then concluded that the addition of the inhibitors to the substrate reduces the roughness, possessing defect free uniform coating, having a low friction coefficient, and a greater corrosion resistance.

\subsection{Lanthanides}

Rare-earth coating that was monopolized by Cerium (Ce) has been extensively studied for the past several years [34-37]. Advantages of the Ce are the acceptable lower cost, eco-friendliness, and compatibility to most of the corrosion inhibitors [59,60]. In 2000, Rudd et al. [34] coated Ce that was discovered by Hilton [61] with $\mathrm{La}\left(\mathrm{NO}_{3}\right)_{3}$ conversion solution. The substrate WE34 was polished prior to the coating immersion. The optimum parameters that were found in this study, for the temperature and the duration, are room and 5 minutes respectively. Findings of the study reveal the potential of the Ce to increase the corrosion resistance three times more than the polarization resistance of the substrate.

Similarly, in 2003 Dabalà et al. [35] had conducted a study to deposit Ce. The substrate of a AZ63 was coated using a conversion deposition solution of $\mathrm{CeCl}_{3}+\mathrm{H}_{2} \mathrm{O}_{2}$ with the parameter of room 
temperature, with 30-180 s of duration. Improvisation on the non-homogenous and large agglomerates were observed throughout this study. Because of the rapid grow on the substrate, after the sixth layer, a failure was recorded.

Su et al. [36] coated Ce on AZ31 Mg alloy in $\mathrm{Ce}\left(\mathrm{NO}_{3}\right)_{3}+\mathrm{H}_{2} \mathrm{O}_{2}$ solution. The conversion solution method with $20 \mathrm{~s}$ pickling in hydrochloric acid shows the enhancement of the adhesion towards the substrate. Blister formation, that induced the enhancement of the characteristics of the coating, was resulted from the Ce oxide layer breaks.

A novel eco-friendly gradient coating fro AZ91D was proposed by Chen et al. [37] in 2009. The deposition method, which is sol-gel, was deposited in a room temperature and was successfully deposited on the substrate. The morphology study of the coating revealed the smooth and compact profile of the coating. This novel approach increased the potential of corrosion inhibitor of the Ce on the substrate.

$\mathrm{La}$ is one of the rare earth-based compounds that has been studied [38,39]. La conversion coating was mainly deposited using conversion solution by utilizing the $\left(\mathrm{NO}_{3}\right)_{3}$ as another rare earth compound [34,36-45,59-61]. The deposition pattern of La and Ce are the same.

Song et al. [38] in 2011 showed that the treatment of La on Mg-Li alloy using a microwave radiation led to equal spread and pack coating. The La coating exhibited greater resistance value of the Tafel fitting data in comparison with La coated with conventional room condition. The reaction of La and the $\mathrm{Mg}-\mathrm{Li}$ alloy produces the absorption of certain metal ions that leads to the conversion of intermetallic composition. This plays a role in reaction inhibitor. The authors recognized the La had the potential of increasing the impedance value.

Recently, Pezzato [39] deposited La on AZ91 with using conversion solution. The deposition was conducted in alkaline solution that consisted of sodium hydroxide and sodium silicate. The study found that $50{ }^{\circ} \mathrm{C}$ and $30 \mathrm{~min}$ were the parameters that ensured optimum deposition. The increase of the corrosion resistance of the deposited coating and the decrease of the corrosion current density up to two orders of external La layer were observed.

A report by Cui et al. [40] presented Gd coating deposited on AZ91 in 2015. Magnesium alloy with its poor corrosion resistance and active chemical activity led to the use of the coating. The coating was deposited using conversion solution $\mathrm{Gd}\left(\mathrm{NO}_{3}\right)_{3}$ and $\mathrm{H}_{2} \mathrm{O}_{2}$, which also were utilized by some other authors $[34,35,40-42,44]$. Carboxylic acid-neodymium enhanced a great corrosion resistance during the test by immersing in $3.5 \% \mathrm{NaCl}$ solution. As the corrosion resistance increased, the corrosion induced current decreased.

Lately, researchers are using coating with environmentally friendly methods [45,62,63], with corrosion resistance superiority [64-68]. Another important element among the rare-earth line-up is the neodymium ( $\mathrm{Nd}$ ). $\mathrm{Nd}$ possess great alloying element to $\mathrm{Mg}$ [69]. A group of researchers in 2014 had deposited $\mathrm{Nd}$ on AZ31 Mg alloy [41]. The study immersed the $\mathrm{Mg}$ in a $\mathrm{Nd}\left(\mathrm{NO}_{3}\right)_{3}+\mathrm{H}_{2} \mathrm{O}_{2}$ solution. After a series of chemical chain reactions and organic sequestering agent reactions, the $\mathrm{Nd}$ coating was deposited. Referring to the work done, the author cleared that the coating exhibited great corrosion resistance. Among all the conversion methods that they had tried, the coating with phytic made the most resistance to corrosion.

Lanthanides ions such as $\mathrm{Nd}$ were famously used to replace toxic compounds such as chromium, and previous works of $\mathrm{Nd}$ are used in the geology application [70]. The microstructure of the $\mathrm{Nd}$ was studied by Jin et al. [42] in 2010, in which they found that the $\mathrm{Nd}$ had a surface of crack-mud like structure. $\mathrm{Nd}$ coating was deposited on AZ91 using conversion solution utilizing $\mathrm{Nd}\left(\mathrm{NO}_{3}\right)_{3}+\mathrm{H}_{2} \mathrm{O}_{2}$ solution. The optimum duration and temperature were recorded at $50{ }^{\circ} \mathrm{C}$ and $20 \mathrm{~min}$. The study indicates that the improved corrosion resistance is due to the $\mathrm{Nd}$ coating.

A series of studies in the past few years had revealed the rare-earth conversion coating characteristics such as anti-carcinogenic [71-74], and high-dose induced effects such as cytotoxic and hepatoxic $[69,75-77]$. A recent study that utilized $\operatorname{Pr}\left(\mathrm{NO}_{3}\right)_{3}$ in conversion solution method deposited Pr on AZNd alloy [43]. The study stated that Pr with less concentration will deposit in a 
shorter time in comparison with more concentration of Pr. The alkaline solution used as pre-treatment was helping the coating to evenly be coated on the substrate. Some insulating layers were formed on the coating.

A study was done in 2013 by Hou et al. [44] to investigate the novel Samarium (Sm) environmentally friendly treatment on AZ91 alloy. AZ91 was prepared by polishing and etching afterwards. In the study, the chrome-free Sm was thoroughly studied micro-morphologically, as well as the corrosion resistance performance. Sm surface morphology was identical to mud-crack and compact. Composition of the Sm coating was mostly made from amorphous samarium oxides. Through the experiment, the Sm coating exhibited improved corrosion resistance of the relevant coated substrate.

Apart from various coating methods available in open literature [78-83], chemical conversion treatment was one of the famous coating methods due to its low cost and simple processes and was utilized in a study by Han et al. [45] in 2017 to deposit Yttrium (Y) rare-earth compound on AZ91D. The AZ91D alloy with a composition of Mg-9.2Al-0.5Zn (wt. \%) was first prepared in a polishing event and later deposited. Post-treatment applied on this study was silica sol solution dipping. The author found out that the $\mathrm{Y}$ coated substrate helps in improving the corrosion resistance, and the corrosion current density was decreased two orders of magnitude.

\subsection{Reactive Non-Metals}

Win [30] in 2011 studied a type of carbon which consists of graphite like $\mathrm{sp}^{2}$ and diamond like $\mathrm{sp}^{3}$ bond called $\mathrm{N}$ doped and $\mathrm{Pt} / \mathrm{Ru} / \mathrm{N}$ doped diamond-like carbon, to optimize the depositing condition of those thin protective coatings. The author's target was to improve the electrical conductivity of the thin protective coating while maintaining the electrochemical properties of the thin protective coating. The thin protective coating was deposited using filtered cathodic vacuum arc and the direct current magnetron sputtering deposition methods. These research findings revealed that several improvements need to be addressed due to the degradation of the corrosion resistance of those thin protective coatings.

Basavakumar et al. [31] in 2007 studied the relationship between the polished and treated diamond coated insert and the surface integrity of machining a cast alloy. A treatment was introduced to Al-7Si and $\mathrm{Al}-7 \mathrm{Si}-2.5 \mathrm{Cu}$ to study the effect of the treatment and to improvise the machinability of the alloys. The treatment was grain refiner (1 wt. \% Al-1Ti-3B), and another one was grain modifier (0.02 wt. $\% \mathrm{Sr}$ ). The treatment established a great surface finish to the alloy when compared to the untreated alloys. They showed the differences of the treated and untreated Al-7Si and Al-7Si-2.5Cu alloys, respectively. Moreover, several tests were conducted in this particular study, namely, microstructure tests, dry machining condition test, surface and the chemical characteristics. Diamond was coated onto a tool's insert by using the chemical vapor deposition method for its remarkable hardness, outstanding resistance to wear, and being a very good candidate for the dry machining application. The grain modification such as combination of refinement and modification, effects the surface finishing on the substrate. Meanwhile, the chemical characteristics done of the chemical vapor deposition coated diamond revealed dwindle down debris on the edge of the insert. The wear on the inserts was also significantly lower than on the uncoated tool. A comparison was made between chemical vapor deposition coated diamond inserts and uncoated inserts.

Prater [32] in 2008 applied one of the most popular carbon allotropies, a diamond to friction stir welding (FSW) tool, as a thin protective coating. With a remarkable hardness, high thermal conductivity, thermal expansion coefficient, and outstanding meting point of 10 Mohs scale, $20 \mathrm{~W} \mathrm{~cm}^{-1} \mathrm{~K}^{-1}$, $1.1 \times 10^{-6} \mathrm{~K}^{-1}$, and $400{ }^{\circ} \mathrm{C}$, respectively, diamond coated tool might be functioning as a good FSW tool. Diamond coating heat sink properties suit the FSW processes that involve high heat from frictional force between the tool and the workpiece. The study utilized a coating process by microwave plasma enhanced chemical vapor deposition technique of the diamond. The process was segregated into several phases such as diffusion, nucleation, and growth, where nucleus of diamond was formed at critical size of the surface concentration. The authors found that diamond thin protective coating 
characteristic helps in reducing the axial force subjected in the process. Reduction of the forces may be beneficial for the welding machine. While forces were reduced, sound welding was still established in this study.

Prater [33], in 2012, came up with a way of using thin protective coating to combat unusual shear wear phenomenon when working with metal matrix composite. This was through the limitation of the amount of wear because of the clearance between the surface of the tool and the plug. The plug was a buffer zone according to the author, and the unusual wear occurred only at places where there was enough width for the plug to span its radius. The author showed the hardness of potential materials for the application of thin protective coating and compared the uncoated tool of uncoated WC-Co pre-weld and post-weld. The tool experienced wear from $4.94 \% \sim 6.76 \%$ of probe wear. There were subtle wear of diamond coated WC-Co tool. An economic way to employ diamond was by deploying the grains of diamond as a thin protective layer using a coating method named chemical vapor deposition. The author concluded that to combat abrasive wear, the hardness of the tool needs to be higher than the hardness of the working material. The reduction of the wear induced by the machining on the metal matrix composite expanded the machinability of the metal matrix composite.

\subsection{Hybrid}

Ever since the development of coating decades before, as mentioned in this study, a broad type of coating has been investigated [53,54,84-87]. This involved hybrid multilayered type. Hybrid coating in this study is a combination of two or more types of nanocomposites in pursuit of a competent and unique material [88], developed to cater to problems in industries.

Tien et al. [89] performed a study in 2006 with multilayer CrN/AlN thin protective coating. The authors aimed to study the microstructure evolution and the composition of the oxide formed of $\mathrm{CrN} / \mathrm{AlN}$, while focusing on the thermal resistance and the resistance to the oxidation at high temperature. Fabricated by using radio frequency magnetron sputtering, it is believed by the authors that the interfaces between layers that play a role for the oxidation resistance of the CrN/AlN thin protective coating in the high temperatures. The $\mathrm{CrN} / \mathrm{AlN}$ thin protective coating in this study also underwent heat treatment at 800 and $950{ }^{\circ} \mathrm{C}$, and the characteristics of the $\mathrm{CrN} / \mathrm{AlN}$ thin protective coating were studied using the electron microscopy characterization. Table 6 shows the chemical properties results of the $\mathrm{CrN} / \mathrm{AlN}$ thin protective coating after heat treatment.

Table 6. CrN/AlN thin protective coating chemical properties [89].

\begin{tabular}{|c|c|c|c|c|c|}
\hline Location & $\mathrm{Cr}$ & Al & O & $\mathbf{N}$ & Phase \\
\hline 1 & 9.9 & 18.9 & 71.2 & - & $\begin{array}{l}\text { Crystalline } \\
\text { Al-rich oxide }\end{array}$ \\
\hline 2 & - & - & - & - & Nano-voids \\
\hline 3 & 17.6 & 16.3 & 66.2 & - & $\begin{array}{c}\text { Mixed } \\
\left(\mathrm{Al}_{\mathrm{x}} \mathrm{Cr}_{1-\mathrm{x}}\right)_{\mathrm{s}} \mathrm{O}_{3}\end{array}$ \\
\hline 4 & 34.3 & 21.8 & - & 43.9 & CrN/AlN film \\
\hline 5 & 5.8 & 27.4 & 66.8 & - & $\begin{array}{l}\text { Amorphous } \\
\text { Al-rich oxide }\end{array}$ \\
\hline 6 & 25.0 & 14.3 & 60.7 & - & $\begin{array}{l}\text { Crystalline } \\
\text { Cr-rich oxide }\end{array}$ \\
\hline 7 & 14.5 & 23.3 & 62.3 & - & $\begin{array}{c}\text { Mixed } \\
\left(\mathrm{Al}_{\mathrm{x}} \mathrm{Cr}_{1-\mathrm{x}}\right)_{\mathrm{S}} \mathrm{O}_{3}\end{array}$ \\
\hline 8 & 8.7 & 25.4 & 65.9 & - & $\begin{array}{l}\text { Amorphous } \\
\text { Al-rich oxide }\end{array}$ \\
\hline 9 & 14.9 & 22.5 & 62.6 & - & $\begin{array}{l}\text { Amorphous } \\
\text { Al-rich oxide }\end{array}$ \\
\hline
\end{tabular}


Sahu [48] in 2012 carried out an experimental work on a $\mathrm{TiCN}+\mathrm{TiC}+\mathrm{TiCN}+\mathrm{Al}_{2} \mathrm{O}_{3}+\mathrm{TiN}$ multilayer thin protective coating that was adopted on a carbide substrate with $\mathrm{Co}, \mathrm{Cr}_{3} \mathrm{C}_{2}$, and $\mathrm{WC}$ value of $6 \mathrm{wt} . \%, 0.5 \mathrm{wt}$ \%, and $93.5 \mathrm{wt}$. \%, respectively. In search of high-quality coating with economic range of production, the outermost layer, TiN, had a low friction coefficient and a property that was anti-adhering. TiN reduced the amount of built-up material on the surface, thus, maintaining the machining ability of the substrate and the quality of the machining itself. The mechanisms that lead to the wear of the thin protective layer were tribochemical, abrasion wear, adhesion strength, and diffusion. The author concluded that the $\mathrm{TiCN}+\mathrm{TiC}+\mathrm{TiCN}+\mathrm{Al}_{2} \mathrm{O}_{3}+\mathrm{TiN}$ multilayer thin protective coating produces surface roughness for the high speed and low rate of feeding application. $\mathrm{TiCN}+\mathrm{TiC}+\mathrm{TiCN}+\mathrm{Al}_{2} \mathrm{O}_{3}+\mathrm{TiN}$ multilayer thin protective coating performed better than the uncoated tool.

An et al. [49] recently studied the wear resistance $(\mathrm{TiB}+\mathrm{TiC}) / \mathrm{Ti} 64$ coating on network structured TMC as a substrate. The deposition method used for this study is the gas tungsten arc cladding process with $11.3 \mathrm{~V}$ and 120 A optimum cladding parameters. Coated network structures TMC (trimesoyl chloride) exhibited remarkable hardness improvement, as well as the slight plastic deformation and abrasion resistance enhancement. This coating appears to have a scale-like pattern under the morphology study done by the author, and the wear mechanisms of this ( $\mathrm{TiB}+\mathrm{TiC}) / \mathrm{Ti} 64$ were observed as brittle debonding, oxidation, and micro ploughing.

Self-lubricating $\mathrm{Ni}-\mathrm{P}-\mathrm{Ag}-\mathrm{Al}_{2} \mathrm{O}_{3}$, coating for instance, was studied by Alirezaei et al. [90] in 2013. Researchers have focused on self-lubrication over the years for an idea to introduce solid lubricant [91-97]. In the study, high temperature information of the coating was introduced. The substrate used in the study is polished medium carbon steel. The authors utilized the electroless bath method and Nickel sulphate $+\mathrm{NaH}_{2} \mathrm{PO}_{2}$ which was used as a solution. The solid lubricating properties of the silver in the coating was believed to be the reason for the modification of the coating's properties. Great wear resistance and 'chameleon' friction coefficient were observed.

Vacuum arc evaporation was used to deposit TiN/MoN on A 570 Grade 36 and AISI M2 as studied by Pogrebnjak et al. [98] in 2014. Vacuum arc is one of the best ways to coat a substrate [50-52,99-107], and the authors had successfully coated and investigated the performance. The coating exhibited random Moiré pattern. The high hardness of $30 \mathrm{GPa}$ was observed with 325-420 GPa elastic modulus. With these findings, the critical loading of the coating increased.

A study by Pogrebnjak et al. [108] in 2017 examined TiN/Zrn coating on A 570 Grade 36. Under different modes; the substrate was first polished and then was coated with Vacuum arc evaporation method. The coating total thickness measured $39 \mathrm{~nm}$. Optimum parameters for the coating observed by the authors were $100 \mathrm{~A}, 0.4 \mathrm{~Pa}, 250 \mathrm{~mm}$ distance from the evaporator, and 2-3 nm/s deposition rate. 500 layers of $19 \mu \mathrm{m}$ coating were observed to enhance the strength due to interface of the coating that prevented dislocation movement.

Recently, CrN/MoN coating has been deposited on 12X18H9T stainless steel using Vacuum arc evaporation method by Pogrebnjak et al. [109]. Multilayers of chromium and molybdenum are believed to induce the high value of hardness [110-116], and the observation on the well-defined multilayer structure of this study confirms it. The coating exerts high hardness value at $42.3 \mathrm{GPa}$, due to Hall-Petch strengthening mechanism.

Compared to homogenous coating, metallic/ ceramic possesses superior properties [105,117-120]. Nordin et al. [105] compared four (TiN/CrN, TiN/MoN, TiN/NbN, and TiN/TaN) coatings on a cemented carbide. In this work, coated cemented carbide beneficially aids on the improvement of the substrate. In general, all the coatings show a potential to be applied wherein the abrasive wear is the dominant factor to be considered.

\section{Conclusions}

A review of the study and research of thin protective coating for the last 25 years has been explored and introduced in this paper. For each one of the thin protective coatings introduced in the industrial 
process, the objective is the same: to gain a deeper knowledge of the effect of harder material on forces exhibited in the work. Thin protective coating is extensively used in the industries. The ultimate goal of continuous development to enhance the capability of the working tool necessary to make working with harder material cost effective, by extending the tool replacement period. Each of the thin protective coatings withstands significant levels of wear; in term of tool's lifespan, diamond thin protective coating is considered as the most practical option.

Author Contributions: Conceptualization, A.A.K. and M.A.; methodology, A.A.K. and M.A.; software, A.A.K. and M.A.; validation, A.A.K., M.A. and S.R.P.; formal analysis, A.A.K. and M.A.; investigation, A.A.K. and M.A.; resources, A.A.K., M.A.; data curation, A.A.K. and M.A.; writing-original draft preparation, A.A.K. and M.A.; writing-review and editing, A.A.K. and M.A.; visualization, A.A.K. and M.A.; supervision, A.A.K. and M.A.; project administration, A.A.K., M.A. and S.R.P.; funding acquisition, A.A.K. and M.A. All authors have read and agreed to the published version of the manuscript.

Funding: This research was funded by Yayasan Universiti Teknologi PETRONAS, grant number 015LC0-129.

Acknowledgments: This research was supported by Universiti Teknologi PETRONAS, Malaysia.

Conflicts of Interest: The authors declare no conflict of interest.

\section{References}

1. Saini, V.K.; Khan, Z.A.; Siddiquee, A.N. Developments in conventional machining of aluminum matrix composite material: A review. Int. J. Adv. Manuf. Technol. 2014, 7, 73-81.

2. Tyagi, A.; Walia, R.S.; Murtaza, Q.; Pandey, S.M.; Tyagi, P.K.; Bajaj, B. A critical review of diamond like carbon coating for wear resistance applications. Int. J. Refract. Met. Hard Mater. 2019, 78, 107-122. [CrossRef]

3. Szeri, A.Z. (Ed.) Tribology: Friction, Lubrication, and Wear; McGraw-Hill: New York, NY, USA, 1980.

4. Prater, T.J. Predictive Process Modeling of Tool Wear in Friction Stir Welding of Metal Matrix Composites; Vanderbilt University: Nashville, TN, USA, 2012.

5. Moore, M.A. The relationship between the abrasive wear resistance, hardness and microstructure of ferritic materials. Wear 1974, 28, 59-68. [CrossRef]

6. Mayrhofer, P.H.; Mitterer, C.; Hultman, L.; Clemens, H. Microstructural design of hard coatings. Prog. Mater. Sci. 2006, 51, 1032-1114. [CrossRef]

7. Petrov, I.; Barna, P.B.; Hultman, L.; Greene, J.E. Microstructural evolution during film growth. J. Vac. Sci. Technol. 2003, 21, S117-S128. [CrossRef]

8. Petrov, I.; Hultman, L.; Helmersson, U.; Sundgren, J.E.; Greene, J.E. Microstructure modification of TiN by ion bombardment during reactive sputter deposition. Thin Solid Film. 1989, 169, 299-314. [CrossRef]

9. Mathiazhagan, A.; Joseph, R. Nanotechnology_A New prospective in organic coating-Review. Int. J. Chem. Eng. Appl. 2011, 2, 225. [CrossRef]

10. Wilson, M.; Kannangara, K.; Smith, G.; Simmons, M.; Raguse, B. Nanotechnology: Basic Science and Emerging Technologies; Chapman and Hall/CRC: Boca Raton, FL, USA, 2002.

11. Sidky, P.S.; Hocking, M.G. Review of inorganic coatings and coating processes for reducing wear and corrosion. Br. Corros. J. 1999, 34, 171-183. [CrossRef]

12. Hedenqvist, P.; Olsson, M.; Wallén, P.; Kassman, Å.; Hogmark, S.; Jacobson, S. How TiN coatings improve the performance of high speed steel cutting tools. Surf. Coat. Technol. 1990, 41, 243-256. [CrossRef]

13. Camp, A.D. Chipping and abrasion tests for paint coatings on chipping and abrasion tests for paint coatings on metal. Ind. Eng. Chem. 1928, 20, 851-852. [CrossRef]

14. Hothersall, A.W. Factors affecting the smoothness and mechanical properties of electrodeposited copper. Trans. IMF 1930, 6, 95-122. [CrossRef]

15. Monk, R.G.; Ellingham, H.J.T. Electrodeposition of tin alloys from alkaline stannate baths. Trans. Faraday Soc. 1935, 31, 1460-1468. [CrossRef]

16. Du Rose, A.H. The protective value of lead and lead-tin deposits on steel. Trans. Faraday Soc. 1946, $89,417-432$.

17. Rybakova, N. Production of Titanium Diboride Coatings by Electrolysis of High-Temperature Molten Salts. Ph.D. Thesis, University of Vienna, Vienna, Austria, 2011. 
18. Young, F.; Davis, B. Scuff-and Wear-Resistant Chemical Coatings; SAE Technical Paper 470250; SAE International: Warrendale, PA, USA, 1947.

19. Killeffer, D.H. Chromium plating-A new aid to industry. Ind. Eng. Chem. 1927, 19, 773-776. [CrossRef]

20. Dubpernell, G. Chromium plating. Electrochem. Soc. 1941, 80, 589-615. [CrossRef]

21. Furman, V.V.; Apininskaya, L.M. Electrophoretic deposition of chromium carbide. Powder Metall. Met. Ceram. 1974, 13, 118-120.

22. Heideman, R.J. Friction Stir Spot Welding of 6061 Aluminum-to-Copper. Ph.D. Thesis, The University of Wisconsin-Madison, Winsconsin, WI, USA, 2014.

23. Corchia, M.; Delogu, P.; Nenci, F.; Belmondo, A.; Corcoruto, S.; Stabielli, W. Microstructural aspects of wear-resistant stellite and colmonoy coatings by laser processing. Wear 1987, 119, 137-152. [CrossRef]

24. Chen, K.J.; Hung, F.Y.; Lui, T.S.; Shih, Y.R. Wear inducing phase transformation of plasma transfer arc coated tools during friction stir welding with $\mathrm{Al}$ alloy. J. Eng. 2019. [CrossRef]

25. Fernandez, J.E.; Rodriguez, R.; Wang, Y.; Vijande, R.; Rincon, A. Sliding wear of a plasma sprayed $\mathrm{Al}_{2} \mathrm{O}_{3}$ coating. Wear 1995, 181, 417-425. [CrossRef]

26. Li, C.J.; Sun, B. Microstructure and property of $\mathrm{Al}_{2} \mathrm{O}_{3}$ coating microplasma-sprayed using a novel hollow cathode torch. Mater. Lett. 2004, 58, 179-183. [CrossRef]

27. Groner, M.D.; Fabreguette, F.H.; Elam, J.W.; George, S.M. Low-temperature $\mathrm{Al}_{2} \mathrm{O}_{3}$ atomic layer deposition. Chem. Mater. 2004, 16, 639-645. [CrossRef]

28. Bahadori, E.; Javadpour, S.; Shariat, M.H.; Mahzoon, F. Preparation and properties of ceramic $\mathrm{Al}_{2} \mathrm{O}_{3}$ coating as TBCs on MCrAly layer applied on Inconel alloy by cathodic plasma electrolytic deposition. Surf. Coat. Technol. 2013, 228, 611-614. [CrossRef]

29. Dezfuli, S.M.; Sabzi, M. Effect of yttria and benzotriazole doping on wear/corrosion responses of alumina-based nanostructured films. Ceram. Int. 2018, 44, 20245-20258. [CrossRef]

30. Win, K.N. Structure and Electrochemical Behavior of Nitrogen Doped Diamond-Like Carbon Thin Films with or without Platinum and Ruthenium Doping. Ph.D. Thesis, Nanyang Technological University, Singapore, 2011.

31. Basavakumar, K.G.; Mukunda, P.G.; Chakraborty, M. Influence of melt treatments and polished CVD diamond coated insert on cutting force and surface integrity in turning of Al-7Si and Al-7Si-2.5 Cu cast alloys. Bull. Mater. Sci. 2007, 30,427-437. [CrossRef]

32. Prater, T. An Investigation into the Friction Stir Welding of Al 6061 and Al 6061/Sic/17.5 P Using Diamond Coatings. Ph.D. Thesis, Vanderbilt University, Nashville, TN, USA, August 2008.

33. Prater, T. Solid-state joining of metal matrix composites: A survey of challenges and potential solutions. Mater. Manuf. Process. 2011, 26, 636-648. [CrossRef]

34. Rudd, A.L.; Breslin, C.B.; Mansfeld, F. The corrosion protection afforded by rare earth conversion coatings applied to magnesium. Corros. Sci. 2000, 42, 275-288. [CrossRef]

35. Dabalà, M.; Brunelli, K.; Napolitani, E.; Magrini, M. Cerium-based chemical conversion coating on AZ63 magnesium alloy. Surf. Coat. Technol. 2003, 172, 227-232. [CrossRef]

36. Su, H.Y.; Li, W.J.; Lin, C.S. Effect of acid pickling pretreatment on the properties of cerium conversion coating on AZ31 magnesium Alloy. J. Electrochem. Soc. 2012, 159, C219-C225. [CrossRef]

37. Chen, B.; Li, Q.; Gao, H.; Fan, J.M.; Tan, X. Microstructural characteristics and corrosion property of non-chromate surface treatments on AZ91D magnesium alloy. Mater. Corros. 2009, 60, 521-526. [CrossRef]

38. Song, D.; Jing, X.; Wang, J.; Lu, S.; Yang, P.; Wang, Y.; Zhang, M. Microwave-assisted synthesis of lanthanum conversion coating on Mg-Li alloy and its corrosion resistance. Corros. Sci. 2011, 53, 3651-3656. [CrossRef]

39. Pezzato, L.; Brunelli, K.; Babbolin, R.; Dolcet, P.; Dabalà, M. Sealing of PEO coated AZ91 magnesium alloy using La-based solutions. Int. J. Corros. 2017, 1-13. [CrossRef]

40. Cui, X.F.; Jin, G.; Yang, Y.Y.; Lin, L.L.; Wang, H.D.; Xu, B.S. Study of gadolinium based protective coating for magnesium alloys. Surf. Eng. 2012, 28, 719-724. [CrossRef]

41. Cui, X.; Liu, Z.; Lin, L.; Jin, G.; Wang, H.; Xu, B. Investigation of carboxylic acid-neodymium conversion films on magnesium alloy. J. Mater. Eng. Perform. 2014, 24, 461-467. [CrossRef]

42. Jin, G.; Yang, Y.; Cui, X.; Liu, E.; Wang, Z.; Li, Q. Chrome-free neodymium-based protective coatings for magnesium alloys. Mater. Lett. 2011, 65, 1145-1147. [CrossRef] 
43. Jamali, S.S.; Moulton, S.E.; Tallman, D.E.; Forsyth, M.; Weber, J.; Mirabedini, A.; Wallace, G.G. Corrosion protection afforded by praseodymium conversion film on $\mathrm{Mg}$ alloy $\mathrm{AZNd}$ in simulated biological fluid studied by scanning electrochemical microscopy. J. Electroanal. Chem. 2015, 739, 211-217. [CrossRef]

44. Hou, L.; Cui, X.; Yang, Y.; Lin, L.; Xiao, Q.; Jin, G. Chrome-free samarium-based protective coatings for magnesium alloys. Phys. Procedia 2013, 50, 261-266. [CrossRef]

45. Han, B.; Gu, D.; Yang, Y.; Fang, L.; Peng, G.; Yang, C. Preparation of yttrium-based rare earth conversion coating and its effect on corrosion resistance of AZ91D magnesium alloy. Int. J. Electrochem. Sci. 2017, 12, 374-385. [CrossRef]

46. Ruth, R.P.; Marinace, J.C.; Dunlap, W.C., Jr. Vapor-deposited single-crystal germanium. J. Appl. Phys. 1960, 31, 995-1006. [CrossRef]

47. Shesternenkov, V.I. Detonation coating. Powder Met. 1968, 7, 30-36. [CrossRef]

48. Sahu, S. Performance Evaluation of Uncoated and Multi Layer Tin Coated Carbide Tool in Hard Turning. Ph.D. Thesis, National Institute of Technology, Rourkela, India, 5 June 2012.

49. An, Q.; Huang, L.; Jiao, Y.; Bao, Y.; Zhong, B.; Geng, L. Intergrowth microstructure and superior wear resistance of $(\mathrm{TiB}+\mathrm{TiC}) / \mathrm{Ti} 64$ hybrid coatings by gas tungsten arc cladding. Mater. Des. 2019, 162, 34-44. [CrossRef]

50. Soderberg, H.; Oden, M.; Larsson, T.; Hultman, L.; Molina-Aldareguia, J.M. Epitaxial stabiliza-tion of cubic-SiN ${ }_{x}$ in TiN/SiN $x$ multilayers. Appl. Phys. Lett. 2006, 88, 191902-1-191902-3. [CrossRef]

51. Gassner, G.; Mayrhofer, P.H.; Kutschey, K.; Mitterer, C.; Kathrei, M. Magneli phase forma-tion of PVD Mo-N and W-N coatings. Surf. Coat. Technol. 2006, 201, 3335-3344. [CrossRef]

52. Pogrebnjak, A.D.; Bratushka, S.N.; Boyko, V.I.; Shamanin, I.V.; Tsvintarnaya, Y.V. A review of mixing process in $\mathrm{Ta} / \mathrm{Fe}$ and $\mathrm{Mo} / \mathrm{Fe}$ systems treated by high current electron beams. NIM B 1998, 145, 373-390. [CrossRef]

53. Tsui, T.Y; Ross, C.A.; Pharr, G.M. Nanoindentation Hardness of Soft Films on Hard Substrates: Effects of the Substrate; Cambridge University Press: Cambridge, UK, 1997; p. 473, MRS Online Proceedings Library Archive.

54. Chen, S.; Liu, L.; Wang, T. Investigation of the mechanical properties of thin films by nanoindentation, considering the effects of thickness and different coating-substrate combinations. Surf. Coat. Technol. 2005, 191, 25-32. [CrossRef]

55. Mikhailov, P.A.; Ponomarenko, E.P.; Petergerya, D.M.; Domio, A.A.; Rybkin, V.F.; Khokhlov, V.P.; Kas' Yanenko, V.G. Endurance and wear resistance of steels with vacuum-diffused coatings. Sov. Mater. Sci. A Transl. Fiz. Khimicheskaya Mekhanika Mater. Acad. Sci. Ukr. SSR 1969, 4, 94-97. [CrossRef]

56. Guzmán Durán, P.A.; Navarro-Devia, J.H.; Aperador Chaparro, W. Machining with cutting tool coated with monolayer of HfN. Tecciencia 2016, 11, 1-6. [CrossRef]

57. Shiozawa, K.; Han, L. The effect of TiN film on low-cycle fatigue behavior of steel coated by PVD method. WIT Trans. Eng. Sci. 1970, 2. [CrossRef]

58. Saini, R.; Roy, D.; Das, A.K.; Dixit, A.R.; Nayak, G.C. Tribological behaviour and characterisation of Ni-WS2 composite coating. Int. J. Surf. Sci. Eng. 2016, 10, 240-252. [CrossRef]

59. Milošev, I.; Rodič, P. Cerium chloride and acetate salts as corrosion inhibitors for aluminum alloy AA7075-T6 in sodium chloride solution. Corrosion 2016, 72, 1021-1034.

60. Aldykewicz, A.J.; Isaacs, H.S.; Davenport, A.J. The investigation of cerium as a cathodic inhibitor for aluminum-copper alloys. J. Electrochem. Soc. 1995, 142, 3342-3350. [CrossRef]

61. Hinton, B.R. The inhibition of aluminum alloy corrosion by cerous cations. Met. Forum 1984, 7, 221.

62. Hamdy, A.S.; Farahat, M. Chrome-free zirconia-based protective coatings for magnesium alloys. Surf. Coat. Technol. 2010, 204, 2834-2840. [CrossRef]

63. Pan, F.; Yang, X.; Zhang, D. Chemical nature of phytic acid conversion coating on AZ61 magnesium alloy. Appl. Surf. Sci. 2009, 255, 8363-8371. [CrossRef]

64. Mosiałek, M.; Mordarski, G.; Nowak, P.; Simka, W.; Nawrat, G.; Hanke, M.; Socha, R.P.; Michalska, J. Phosphate-permanganate conversion coatings on the AZ81 magnesium alloy: SEM, EIS and XPS studies. Surf. Coat. Technol. 2011, 206, 51-62. [CrossRef]

65. Barranco, V.; Carmona, N.; Galván, J.C.; Grobelny, M.; Kwiatkowski, L.; Villegas, M.A. Electrochemical study of tailored sol-gel thin films as pre-treatment prior to organic coating for AZ91 magnesium alloy. Prog. Org. Coat. 2010, 68, 347-355. [CrossRef] 
66. Zucchi, F.; Frignani, A.; Grassi, V.; Trabanelli, G.; Monticelli, C. Stannate and permanganate conversion coatings on AZ31 magnesium alloy. Corros. Sci. 2007, 49, 4542-4552. [CrossRef]

67. Zhou, W.; Shan, D.; Han, E.H.; Ke, W. Structure and formation mechanism of phosphate conversion coating on die-cast AZ91D magnesium alloy. Corros. Sci. 2008, 50, 329-337. [CrossRef]

68. Takenaka, T.; Ono, T.; Narazaki, Y.; Naka, Y.; Kawakami, M. Improvement of corrosion resistance of magnesium metal by rare earth elements. Electrochim. Acta 2007, 53, 117-121. [CrossRef]

69. Haley, T.J.; Raymond, K.; Komesu, N.; Upham, H.C. Toxicological and pharmacological effects of gadolinium and samarium chlorides. Br. J. Pharmacol. Chemother. 1961, 17, 526-532. [CrossRef]

70. Tanaka, T.; Togashi, S.; Kamioka, H.; Amakawa, H.; Kagami, H.; Hamamoto, T.; Yuhara, M.; Orihashi, Y.; Yoneda, S.; Shimizu, H.; et al. JNdi-1: A neodymium isotopic reference in consistency with LaJolla neodymium. Chem. Geol. 2000, 168, 279-281. [CrossRef]

71. Dai, Y.; Li, J.; Li, J.; Yu, L.; Dai, G.; Hu, A.; Yuan, L.; Wen, Z. Effects of rare earth compounds on growth and apoptosis of leukemic cell lines. In Vitro Cell. Dev. Biol. Anim. 2002, 38, 373-375. [CrossRef]

72. Ji, Y.J.; Xiao, B.; Wang, Z.H.; Cui, M.Z.; Lu, Y.Y. The suppression effect of light rare earth elements on proliferation of two cancer cell lines. Biomed. Environ. Sci. 2000, 13, 287-292. [PubMed]

73. Kostova, I.; Momekov, G.; Stancheva, P. New samarium (III), gadolinium (III), and dysprosium (III) complexes of coumarin-3-carboxylic acid as antiproliferative agents. Met. Based Drugs 2007. [CrossRef] [PubMed]

74. Magda, D.; Miller, R.A. Motexafin gadolinium: A novel redox active drug for cancer therapy. Semin. Cancer Biol. 2006, 16, 466-476. [CrossRef] [PubMed]

75. Bruce, D.W.; Hietbrink, B.E.; DuBois, K.P. The acute mammalian toxicity of rare earth nitrates and oxides. Toxicol. Appl. Pharmacol. 1963, 5, 750-759. [CrossRef]

76. Nakamura, Y.; Tsumura, Y.; Tonogai, Y.; Shibata, T.; Ito, Y. Differences in behavior among the chlorides of seven rare earth elements administered intravenously to rats. Toxicol. Sci. 1997, 37, 106-116. [CrossRef]

77. Yang, W.; Zhang, P.; Liu, J.; Xue, Y. Effect of long-term intake of $\mathrm{Y}^{3+}$ in drinking water on gene expression in brains of rats. J. Rare Earths 2006, 24, 369-373. [CrossRef]

78. Ramezanzadeh, B.; Vakili, H.; Amini, R. Improved performance of cerium conversion coatings on steel with zinc phosphate post-treatment. J. Ind. Eng. Chem. 2015, 30, 225-233. [CrossRef]

79. Yi, A.; Du, J.; Wang, J.; Mu, S.; Zhang, G.; Li, W. Preparation and characterization of colored Ti/Zr conversion coating on AZ91D magnesium alloy. Surf. Coat. Technol. 2015, 276, 239-247. [CrossRef]

80. Zhang, D.; Gou, Y.; Liu, Y.; Guo, X. A composite anodizing coating containing superfine $\mathrm{Al}_{2} \mathrm{O}_{3}$ particles on AZ31 magnesium alloy. Surf. Coat. Technol. 2013, 236, 52-57. [CrossRef]

81. Zhu, L.; Li, Y.; Li, W. Influence of silica sol particle behavior on the magnesium anodizing process with different anions addition. Surf. Coat. Technol. 2008, 202, 5853-5857. [CrossRef]

82. Christoglou, C.; Voudouris, N.; Angelopoulos, G.N.; Pant, M.; Dahl, W. Deposition of aluminium on magnesium by a CVD process. Surf. Coat. Technol. 2004, 184, 149-155. [CrossRef]

83. Davies, J.L.; Glover, C.F.; Van De Langkruis, J.; Zoestbergen, E.; Williams, G. The effect of Mg concentration on the resistance of PVD Zn-Mg coatings to corrosion driven organic coating delamination. Corros. Sci. 2015, 100, 607-618. [CrossRef]

84. Charitidis, C.; Laskarakis, A.; Kassavetis, S.; Gravalidis, C.; Logothetidis, S. Optical and nanomechanical study of anti-scratch layers on polycarbonate lenses. Superlattices Microstruct. 2004, 36, 171-179. [CrossRef]

85. Roche, S.; Pavan, S.; Loubet, J.L.; Barbeau, P.; Magny, B. Influence of the substrate characteristics on the scratch and indentation properties of UV-cured clearcoats. Prog. Org. Coat. 2003, 47, 37-48. [CrossRef]

86. Geng, K.; Yang, F.; Grulke, E.A. Nanoindentation of submicron polymeric coating systems. Mater. Sci. Eng. 2008, 479, 157-163. [CrossRef]

87. Zhang, T.H.; Huan, Y. Nanoindentation and nanoscratch behaviors of DLC coatings on different steel substrates. Compos. Sci. Technol. 2005, 65, 1409-1413. [CrossRef]

88. Drisko, G.L.; Sanchez, C. Hybridization in materials science-evolution, current state, and future aspirations. Eur. J. Inorg. Chem. 2012, 32, 5097-5105. [CrossRef]

89. Tien, S.K.; Lin, C.H.; Tsai, Y.Z.; Duh, J.G. Oxidation behavior, microstructure evolution and thermal stability in nanostructured CrN/AlN multilayer hard coatings. J. Alloys Compd. 2010, 489, 237-241. [CrossRef]

90. Alirezaei, S.; Monirvaghefi, S.M.; Saatchi, A.; Ürgen, M.; Motallebzadeh, A. High temperature friction and wear behaviour of $\mathrm{Ni}-\mathrm{P}-\mathrm{Ag}-\mathrm{Al}_{2} \mathrm{O}_{3}$ hybrid nanocomposite coating. Trans. IMF 2013, 91, 207-213. [CrossRef] 
91. Skarvelis, P. Papadimitriou GD. Microstructural and tribological evaluation of potential self-lubricating coatings with MoS2 $\backslash \mathrm{MnS}$ additions produced by the plasma transferred arc technique. Tribol. Int. 2009, 42, 1765-1770. [CrossRef]

92. Yang, M.S.; Liu, X.B.; Fan, J.W.; He, X.M.; Shi, S.H.; Fu, G.Y.; Wang, M.D.; Chen, S.F. Microstructure and wear behaviors of laser clad $\mathrm{NiCr} / \mathrm{Cr}_{3} \mathrm{C}_{2}-\mathrm{WS}_{2}$ high temperature self-lubricating wear-resistant composite coating. Appl. Surf. Sci. 2012, 258, 3757-3762. [CrossRef]

93. Lu, X.L.; Liu, X.B.; Yu, P.C.; Shai, Y.J.; Qiao, S.J.; Wang, M.D.; Wang, Y.G.; Chen, Y. Effects of heat treatment on microstructure and mechanical properties of Ni60/h-BN self-lubricating anti-wear composite coatings on 304 stainless steel by laser cladding. Appl. Surf. Sci. 2015, 355, 350-358. [CrossRef]

94. Piasecki, A.; Kotkowiak, M.; Kulka, M. Self-lubricating surface layers produced using laser alloying of bearing steel. Wear 2017, 376, 993-1008. [CrossRef]

95. Liu, X.B.; Zheng, C.; Liu, Y.F.; Fan, J.W.; Yang, M.S.; He, X.M.; Wang, M.D.; Yang, H.B.; Qi, L.H. A comparative study of laser cladding high temperature wear-resistant composite coating with the addition of self-lubricating WS2 and WS2/(Ni-P) encapsulation. J. Mater. Process Technol. 2013, 213, 51-58. [CrossRef]

96. Fang, L.Y.; Yan, H.; Yao, Y.S.; Zhang, P.L.; Gao, Q.S.; Qin, Y. Reactive fabrication and effect of $\mathrm{NbC}$ on microstructure and tribological properties of $\mathrm{CrS}$ Co-based self-lubricating coatings by laser cladding. Materials 2018, 11, 44. [CrossRef] [PubMed]

97. Yan, H.; Wang, A.H.; Zhang, X.L.; Huang, Z.W.; Wang, W.Y.; Xie, J.P. Nd: YAG laser cladding Ni base alloy/nano-h-BN self-lubricating composite coatings. Mater. Sci. Technol. 2010, 26, 461-468. [CrossRef]

98. Pogrebnjak, A.D.; Eyidi, D.; Abadias, G.; Bondar, O.V.; Beresnev, V.M.; Sobol, O.V. Structure and properties of arc evaporated nanoscale TiN/MoN multilayered systems. Int. J. Refract. Met. Hard Mater. 2015, 48, $222-228$. [CrossRef]

99. Meng, Q.; Wen, M.; Liu, P.; Zhang, K.; Zheng, W. Correlation between interfacial electronic structure and mechanical properties of ZrN/SiNxfilms. Mater. Lett. 2013, 94, 61-64. [CrossRef]

100. Abadias, G.; Guerin, P. In situ stress evolution during magnetron sputtering of transition metal nitride thin films. Appl. Phys. Lett. 2008, 93, 111908. [CrossRef]

101. Pogrebnjak, A.D. Investigation of element profiles, defects, phase composition andphysical and mechanical properties of superhard coatings Ti-Hf-Si-N. Mater. Sci. Appl. 2013, 4, 24-31.

102. Wen, M.; Meng, Q.; Hu, C.; Au, T.; Su, Y.; Yu, W. Structure and mechanical properties of $\sigma-\mathrm{NbN} / \mathrm{SiNx}$ and $\sigma^{\prime}-\mathrm{NbN} / \mathrm{SiNx}$ nano-multilayer films deposited by reactive magne-tron sputtering. Surf. Coat. Technol. 2009, 203, 1702-1708. [CrossRef]

103. Lao, J.; Shao, N.; Mei, F.; Li, G.; Gu, M. Mutual promotion effect of crystal growth in TiN/SiC nanomultilayers. Appl. Phys. Lett. 2005, 86, 011902-1-011902-3. [CrossRef]

104. Setoyama, M.; Nakayama, A.; Tanaka, M.; Kitagawa, N.; Nomura, T. Formation of cubic AlNin TiN/AlN superlattice. Surf. Coat. Technol. 1996, 86-87, 225-230. [CrossRef]

105. Nordin, M.; Larsson, M.; Hogmark, S. Mechanical and tribological properties of multi-layered PVD TiN/CrN, TiN/MoN, TiN/NbN and TiN/TaN coatings on cemented carbide. Surf. Coat. Technol. 1998, 106, 234-241. [CrossRef]

106. Musil, J. Hard nanocomposite coatings: Thermal stability, oxidation resistance and toughness. Surf. Coat. Technol. 2012, 207, 50-65. [CrossRef]

107. Martev, I.N.; Dechev, D.A.; Ivanov, N.P.; Uzunov, T.D.; Kashchiev, E.P. Nanolaminated TiN/Mo2N hard multilayer coatings. J. Phys. Conf. Ser. 2010, 223, 012019. [CrossRef]

108. Pogrebnjak, A.; Ivashchenko, V.; Bondar, O.; Beresnev, V.; Sobol, O.; Załęski, K.; Postolnyi, B. Multilayered vacuum-arc nanocomposite TiN/ZrN coatings before and after annealing: Structure, properties, first-principles calculations. Mater. Charact. 2017, 134, 55-63. [CrossRef]

109. Pogrebnjak, A.D.; Beresnev, V.M.; Bondar, O.V.; Postolnyi, B.O.; Zaleski, K.; Coy, E.; Araujo, J.P. Superhard $\mathrm{CrN} / \mathrm{MoN}$ coatings with multilayer architecture. Mater. Des. 2018, 153, 47-59. [CrossRef]

110. Koshy, R.A.; Graham, M.E.; Marks, L.D. Synthesis and characterization of CrN/Mo2N multilayers and phases of Molybdenum nitride. Surf. Coat. Technol. 2007, 202, 1123-1128. [CrossRef]

111. Koshy, R.A.; Graham, M.E.; Marks, L.D. Temperature activated self-lubrication in CrN/Mo2N nanolayer coatings. Surf. Coat. Technol. 2010, 204, 1359-1365. [CrossRef] 
112. Han, B.; Wang, Z.; Devi, N.; Kondamareddy, K.K.; Wang, Z.; Li, N.; Zuo, W.; Fu, D.; Liu, C. RBS depth profiling analysis of (Ti, Al) N/MoN and CrN/MoN multilayers. Nanoscale Res. Lett. 2017, 12, 161. [CrossRef] [PubMed]

113. Navinšek, B.; Panjan, P.; Milošev, I. Industrial applications of CrN (PVD) coatings, deposited at high and low temperatures. Surf. Coat. Technol. 1997, 97, 182-191. [CrossRef]

114. Gilewicz, A.; Warcholinski, B. Deposition and characterisation of Mo2N/CrN multilayer coatings prepared by cathodic arc evaporation. Surf. Coat. Technol. 2015, 279, 126-133. [CrossRef]

115. Jauberteau, I.; Bessaudou, A.; Mayet, R.; Cornette, J.; Jauberteau, J.; Carles, P.; Merle-Méjean, T. Molybdenum nitride films: Crystal structures, synthesis, mechanical, electrical and some other properties. Coatings 2015, 5, 656-687. [CrossRef]

116. Postolnyi, B.O.; Beresnev, V.M.; Abadias, G.; Bondar, O.V.; Rebouta, L.; Araujo, J.P.; Pogrebnjak, A.D. Multilayer design of $\mathrm{CrN} / \mathrm{MoN}$ protective coatings for enhanced hardness and toughness. J. Alloy. Compd. 2017, 725, 1188-1198. [CrossRef]

117. Larsson, M.; Bromark, M.; Hedenqvist, P.; Hogmark, S. Deposition and mechanical properties of multilayered PVD Ti-TiN. Surf. Coat. Technol. 1995, 202, 76-77. [CrossRef]

118. Larsson, M.; Bromark, M.; Hedenqvist, P.; Hogmark, S. Deposition and microstructure of PVD TiN NbN multilayred coatings by combined reactive electron beam evaporation and DC sputtering. Surf. Coat. Technol. 1996, 351, 86-87.

119. Wiklund, U.; Hedenqvist, P.; Hogmark, S.; Stridh, B.; Arbell, M. Multilayer coatings as corrosion protection of Zircaloy. Surf. Coat. Technol. 1996, 530, 86-87. [CrossRef]

120. Panjan, P.; Navinsek, B.; Milosev, I. Oxidation of TiN, ZrN, TiZrN, CrN, TiCrN and TiN/CrN multilayer hard coatings reactively sputtered at low temperature. Thin Solid Film. 1996, 298, 281-282. [CrossRef]

(C) 2019 by the authors. Licensee MDPI, Basel, Switzerland. This article is an open access article distributed under the terms and conditions of the Creative Commons Attribution (CC BY) license (http://creativecommons.org/licenses/by/4.0/). 